\title{
Financial Ratio Analysis as a Prediction Tool of Bankruptcy on Banking Companies Listed in Indonesia Stock Exchange
}

\author{
Dian Primanita Oktasari ${ }^{1} \quad$ Winda Widyanty $^{2}$ \\ Fakultas Ekonomi dan Bisnis, Universitas Mercu Buana
}

\begin{abstract}
This study aims to analyze the financial ratios of banks to predict bank bankruptcy in Indonesia. Variables used by a number of seven bank financial ratios are CAR, LDR, NPL, BOPO, ROA, ROE and NIM. The research data is obtained by census which means the whole population is used in the research which is 40 banks in year 2017 . The analysis tool used is logit regression. The results of the multivariate test showed that the LDR variable had a significant effect on the profitability of bankruptcy of banks in Indonesia at $\alpha>5 \%$ but did not have the same sign as predicted. CAR, NPL, BOPO, ROE, and NIM variables have the same mark as the predicted but not significant. The ROA variable is not significant and has a different sign than predicted. In general, the results do not accept all Ha.
\end{abstract}

Keywords: bank, bankruptcy, bank financial ratio, bankruptcy.

DOI: $10.7176 / \mathrm{EJBM} / 11-15-05$

Publication date:May $31^{\text {st }} 2019$

\section{Introduction}

Various financial institutions grow as the economy grows. One of the financial institutions that seem to have the most important role in economy is banking financial institution, which are commonly referred as bank. Bank is a kind of financial institution in which companies, government and private institutions, as well as individuals save their funds. Through providing loan and various services, banks serve financial needs and launch payment system mechanism for all economic sectors.

Banking plays an important role in people's lives. Banking is a company in which its activities directly deal with the society. Banking activities are much influenced by the trust from its customers or community. If there is disturbance within the institution, there will be strong reaction from the people.

During the economic crisis which began with the liquidation of sixteen banks in November 1997 and later on 13 March 1999 as thirty eight other banks were declared to be failed to continue their activities. There are two types of distress, namely economic distress and financial distress. Economic distress of a company is associated with an imbalance between revenue and expenditure. Economic distress can be also caused by the company's capital costs which are higher than the profit rate on historical cost of investment. Meanwhile, a company is categorized as financially distressed if the company is unable to pay its due date liabilities although the total assets exceed its liabilities.

Tabel 1.1

Banking Performance 2015-2018

\begin{tabular}{|c|c|c|c|c|c|c|c|c|c|c|c|c|c|c|c|c|}
\hline \multicolumn{17}{|c|}{$\begin{array}{l}\text { Tabel 1.25. Kinerja Bank Umum Konvensional } \\
\text { (Commercial Banks Performance) } \\
\text { Miliar Rp (Billion Rp) }\end{array}$} \\
\hline \multirow{2}{*}{ Keterangan } & \multirow{2}{*}{2015} & \multirow{2}{*}{2016} & \multicolumn{2}{|c|}{2017} & \multicolumn{11}{|c|}{2018} & \multirow{2}{*}{ Homs } \\
\hline & & & Nov & Des & Jan & Fob & Mar & Apr & Mei & Jun & Jul & Ags & Sop & Okt & Nov & \\
\hline 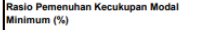 & 21,39 & 22,93 & 23,37 & 23,18 & 23,43 & 23,24 & 22,65 & 22,25 & 22,19 & 22,01 & 22,56 & 22,83 & 22,91 & 22,97 & 23,32 & Capotata Adequacy Raso (s) \\
\hline Modal & 914.657 & 1.052 .597 & 1.157.064 & 1.166.002 & 1.175 .6066 & ${ }^{1.177 .340}$ & 1.161.653 & 1.160 .316 & 1.166.181 & 1.176 .676 & 1.198. 170 & 1213.589 & 1.226 .367 & 1.240 .430 & 1.251.213 & Captal \\
\hline ATMR & 4.276.555 & 4.589.611 & ${ }^{4.951 .148}$ & 5.029.816 & 5.017 .974 & 5.0055992 & 5.120 .158 & 5.213 .753 & 5.254.403 & 5.355 .488 & 5.311 .506 & 5.315028 & 5.3538466 & 5.400.055 & 5.364 .358 & Risk Weighted A Assets \\
\hline Rasio Modal Int terhadap ATMR (":) & 19,00 & 21,19 & 21,69 & 21,50 & 21,77 & 21,58 & 20,98 & 20,50 & 20,45 & 20,42 & 20,92 & 21,09 & 21,19 & 21,25 & 21,59 & Core Capital Ratio to ATMR (4) \\
\hline Modal int (Tier) & 812.590 & 972.350 & 1.073 .893 & 1.081 .234 & 1.092 .477 & ${ }_{1.033 .381}$ & 1.076.311 & 1.068.586 & 1.074.729 & 1.091.769 & 1.110.931 & 1.120 .955 & 1.134.279 & 1.477 .625 & 1.158 .069 & Core Captal (Therl) \\
\hline ATMR & 4276.555 & 4589.611 & 4.951.148 & 5.029.816 & 5.017 .974 & 5005.592 & 5.122 .158 & 5.213 .753 & 5.25.4418 & 5.355 .488 & 5.311 .506 & 5.315 .028 & 5.353846 & 5.400 .055 & 5.364 .358 & Risk Weghnted Assets \\
\hline Retur On Assets Ratio (\%) & 2,32 & 2,23 & 2,48 & 2,45 & 2,50 & 2,36 & 2,55 & 2,40 & 2,38 & 2,43 & 2,46 & 2,47 & 2,50 & 2,52 & 2,52 & Return On Assets Ratio (\%) \\
\hline - Labos sebeclum palak & 132601 & 136.048 & 166.121 & 165.196 & 175.466 & 166.526 & 180.570 & 170.74 & 169789 & 173.853 & 177.127 & 177.908 & 181.016 & 183.358 & 183.776 & Proftr \\
\hline Rata-ratat otota aset & 5.703 .813 & 6.106.959 & 6.696 .785 & 6.730.350 & 7.020 .879 & 70.099 .879 & 7.078 .453 & 7.0999 .936 & $7,130.626$ & 7.168225 & 7.187.449 & 7.208 .105 & 7.228 .14 & 7.262056 & 7.200.052 & - Average total assets \\
\hline $\begin{array}{l}\text { operastional thdp Pendat } \\
\text { sional (rot) }\end{array}$ & 81,49 & 82,22 & 78,37 & 78,64 & 81,80 & 81,09 & 78,76 & 79,50 & 79,43 & 79,46 & 79,05 & 79,26 & 79,13 & 78,71 & 78,03 & operating Expenses Operating II \\
\hline Biaya Operasional & 569.141 & 624.173 & 546.822 & 600.178 & 68.078 & 113.344 & 162.597 & 215.324 & 265.633 & 322.902 & 374211 & 432.358 & 490.120 & 536.041 & 580.228 & Operating Expenseses \\
\hline Pendapatan Operasional & 698.404 & 759.146 & 697.707 & 766.975 & 83228 & 139.780 & 206.441 & 270.531 & 33.4.423 & 406.359 & 473.387 & 545.460 & 619.357 & 681.014 & 743.585 & Operating income \\
\hline erest Margin Ratio (\%) & 5,39 & 5,63 & 5,31 & 5,32 & 5,19 & 5,00 & 5,07 & 5,07 & 5,09 & 5,11 & 5,12 & 5,14 & 5,14 & 5,13 & 5,12 & Net interest Margin Ratio $\%$ ) \\
\hline Pendapatan bunga bersin & 293.824 & 329.913 & 340.285 & 342.731 & 348.992 & 338.024 & 343.588 & 345.001 & 347.684 & 350.332 & 352305 & 354.475 & 355.47 & 356.825 & 357.833 & Interesst ncomene net \\
\hline Ratar atat totat aset productif & 5.449 .642 & 5854.786 & 6.413.890 & 6.445.076 & 6.729 .232 & 6.755.97r & 6.782807 & 6.801.445 & 6.825 .468 & 6.850225 & 6.877219 & 6.896.128 & 6.917 .324 & 6.952549 & 6.981 .469 & Average tostal eanning assets \\
\hline oan to Deposits Ratio (\%) & 92,11 & 90,70 & 88,97 & 90,04 & 89,10 & 89,21 & 90,19 & 90,43 & 91,99 & 92,76 & 93,11 & 93,79 & 94,09 & 93,71 & 93,19 & Lam to Deposits Ratio (x) \\
\hline 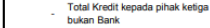 & 3.903.936 & 4.199 .713 & 4.418 .713 & 4.548.155 & 4.445 .801 & 4474893 & 4.553 .173 & 4.587.122 & 4.668 .549 & 4.784.436 & 4.784 .803 & 4.839.567 & 4.921.548 & 4.970 .100 & 4.960.336 & - Total Croste fo thited pary \\
\hline Total Dana Pinak Ketigga & 4238.399 & 4.630.352 & ${ }_{4.966 .736}$ & 5.050.084 & 4.989.468 & 5.016 .043 & 5.048278 & 5.072 .433 & 5.004.582 & 5.157 .74 & 5.138.722 & 5.160 .189 & 5.230 .022 & 5.303 .577 & 5.322 .634 & Total Mird Party Funds \\
\hline Likuld (\%) & 16,70 & 17,50 & 18,09 & 18,56 & 18,23 & 18,11 & 17,91 & 17,36 & 17,19 & 16,68 & 15,64 & 15,41 & 15,35 & 15,39 & 15,58 & Assets Ratio (x) \\
\hline Aset Likuid Primer & 736.720 & 837.433 & 893.406 & 963.833 & 920.320 & 901.106 & 922098 & 921.995 & 984.962 & 986.041 & 823.382 & 816.952 & 82.1980 & 843.3.14 & 860.438 & Primay Liquid Asset \\
\hline Aset Likidid Selunder & 25.623 & 206.098 & 362.824 & 353.504 & 359.304 & 380.975 & $\begin{array}{r}354.856 \\
\quad\end{array}$ & 321.754 & ${ }^{261.775}$ & ${ }^{263243}$ & 31.0086 & 316.172 & 323.418 & 322236 & 319.336 & Secondary Livuid assets \\
\hline Total Aset & 5.919.390 & & 6.944.188] & & & 7.078.879 & & & 7.253 .384 & & & & & & 7.52810 & Totat Assets \\
\hline
\end{tabular}

Source: Statistik Perbankan Indonesia Vol 16 No12, Nov 2018, www.ojk.go.id

From the table above it can be seen that the Bank's performance in November 2018 CAR (23.32\%), Core Capital ratio to ATMR (21.59\%), ROA (2.52\%), Operating Expense / Operating Income (78.03\%) ), NIM (5.12\%), LDR (93.19\%), Liquid Asset Ratio (15.58\%). 
Bankruptcy may be triggered by various factors, both directly and indirectly. Banks can go bankrupt and must be closed if their performance is poor due to high numbers of non-performing loans or assets. Moreover, bank had liquidity problems due to massive withdrawals at one time since systemic crisis, bank run, and public distrust of the bank. Liquidity problems can also be caused by a mismatch of short-term funding structures.

Company's performance can be measured by using financial statements. The bank's financial statements consist of balance sheet provide information about financial position, income statement to assess the bank's operational development, statement of cash flows that provide information on cash turnover. Financial statement not only reflects the condition of a company in the past but it can also be used to predict the financial condition of a company in the future (Pankof and Virgil in Suharman, 2007). Nurhayati (2013) said that company's high value indicated high prosperity that every company wants to achieve.

One of the techniques used to assess companies is financial ratio analysis. Indicators of bank's performance can be viewed from liquidity, profitability, bank risk, capital ratio and business efficiency ratio. Liquidity ratio assesses the company's ability to meet short-term liabilities. Profitability ratio assesses the company's ability to make profit. Business risk ratio assesses the risks in running a business. Capital ratio measures the ability of capital to cover losses. Business efficiency ratio measures the level of efficiency of the company. The financial ratio is expected to be used to detect financial distress.

The bankruptcy prediction model is used as a means of early warning of financial distress, that is, it can improve conditions before reaching a crisis or bankruptcy condition (Endri, 2009).

\section{Literature Review}

Financial Statement

The final result of financial records is financial statements. Financial statements are reflection of management's achievements in particular period. By analyzing the financial statements of a company, the management's performance can be identified during particuar period of time. However, financial statements is not the only aspect to reflect the actual achievements.

The most important role of financial statements in management is as accountability of report. The report is written in the form of financial statements to present the financial position and results in a certain period based on the accounting principles.

Fraser and Ailen Orminston (2004: 1-2) explained that financial statements are the fundamental to understand financial position of a company, to assess past performance and to predict financial performance in the future. He added that financial statements has the ability to clearly present the financial health of a company to make informative business decisions".

It can be concluded that financial statements generally consist of balance sheet and also profit and loss statements, but in fact, some additional reports are often used to support financial statements and provide further explanations such as capital statement, statement of cash flows, and others.

\section{Bank Liquidity Theories}

There are four renowned banking liquidity theories (Veitzhal, 2007: 387):

a. Commercial Loan theory

It is considered to be the oldest theory; it is also known as the doctrine real bills. This theory began about two centuries ago. The study of this theory was conducted by Adam Smith in his famous book The Wealth of Nations, published in 1776. This theory assumes that banks can only provide loans with self-liquidating shortterm commercial loans. Self-liquidating means the loan is used for repayment.

b. Shiftability Theory

This theory is based on the proposition that the assets of the banks are either to be sold to other lenders or investors or shifted to central bank which stands ready to purchase assets offered for sale.

If the depositors decide to withdraw their money, the bank will only sell the investment, take what is obtained (or purchased), and repay to the depositor.

c. Anticipated Income Theory

In 1940 this theory was prominent in the United States; it is also known as the anticipated income theory. It means all funds allocated or every effort allocating funds is shown in a feasible sector that will be beneficial for the bank.

d. The Liability Management Theory

In liability management theory, banks should manage their liabilities properly to be a source of liquidity. The required liquidity for banks is:

1) Deal with withdrawals

2) Fulfill bank's obligations

3) Provide loans 


\section{Bankruptcy}

The terms used in this study is to identify some banking problems such as bankruptcy (Altman, 1968; Ohlson, 1980; Barniv et all, 2002); bank failure (Meyer and Pifer, 1970), bank problems (Sinkey, 1975; Santoso, 1996), financial distress (Platt and Platt, 2002). Banks that failed in businesses have one or both of the following two criteria:

Firstly, the bank needs financial support and or management support from the government in running its operations.

Secondly, based on the level of bank financial health it is categorized as less healthy and unhealthy (Santoso in Suharman, 2007). Foster (1986) used the term financial distress to show severe liquidity problems that cannot be solved without a large scaling of corporate operations or structures.

At some points, financial distress is the best view as a whole economic idea/ thought. Empirical research about this subject area has objective criteria for categorizing companies. Bankruptcy is a criterion used in many studies. This is a legal event that can be affected by the actions of bankers or other creditors. Even if the presumption of financial distress is binary, it is not necessary to be one-to-one categories between non-distressed/ distressed and non-bankrupt/bankrupt.

According to Farid and Siswanto (in Januarti, 2002), in determining the bankruptcy model through financial analysis, classification of error can be classified into two:

- $\quad$ Type I error

This type of error occurs when there is a prediction that the company is not bankrupt, but it turns out to be bankrupt.

- $\quad$ Type II error

This type of error occurs when there is a prediction that the company is bankrupt, but it turns out to be not bankrupt.

\section{Indicators of Financial Distress or Bankruptcy}

According to Foster (1986), there are some indicators or sources of information about financial failure or bankruptcy:

a) Current and future cash flows analysis to directly focus on the alleged bankruptcy for the concerned period. Cash flows estimation in this analysis is critical variables as the assumptions that underlie budgeting.

b) Company strategy analysis considers potential competitors of the company or institution, relative cost structure, building expansion in the industry, company's ability to continue increasing costs, management quality, and so on. In this theory, such consideration will also underlie cash flow analysis. However a separate focus on the problem of strategy can highlight the consequences of sudden changes in an industry, for example: BEP testing and cost structure.

c) Company financial statements with company comparisons analysis focused on single financial variables (univariate analysis) or a combination of financial variables (multivariate analysis) with external variables such as return securities or bond ratings.

\section{Research Hypothesis}

Based on the previous studies, CAR, LDR, NPL, BOPO, ROA, ROE, and NIM have influence on probability of bank financial distress in Indonesia. Therefore, the hypotheses of this research are as follow:

a. $\mathrm{H}_{\mathrm{a} 1}=\mathrm{CAR}$ have negative influence on probability of bank financial distress in Indonesia

b. $\mathrm{H}_{\mathrm{a} 2}=\mathrm{LDR}$ have positive influence on probability of bank financial distress in Indonesia

c. $\mathrm{H}_{\mathrm{a} 3}=$ NPL have positive influence on probability of bank financial distress in Indonesia

d. $\mathrm{H}_{\mathrm{a} 4}=\mathrm{BOPO}$ have positive influence on probability of bank financial distress in Indonesia

e. $\mathrm{H}_{\mathrm{a} 5}=\mathrm{ROA}$ have negative influence on probability of bank financial distress in Indonesia

f. $\mathrm{H}_{\mathrm{a} 6}=\mathrm{ROE}$ have negative influence on probability of bank financial distress in Indonesia

g. $\mathrm{H}_{\mathrm{a} 7}=$ NIM have negative influence on probability of bank financial distress in Indonesia 


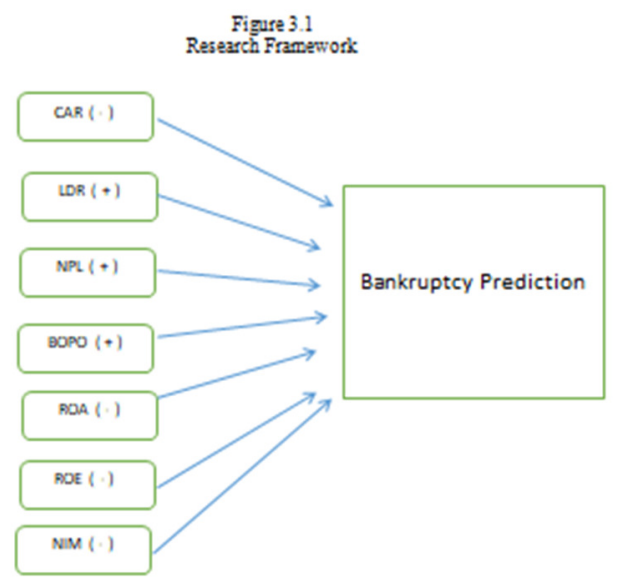

\section{Research Method}

The population in this research is 40 banking companies listed in Indonesia Stock Exchange during 2017. The prediction model of the next following year tends to be more accurate (Suharman, 2007). The sample was obtained through census in which the population used as the data. Census is applied to obtain real value (Supranto, 2003).

The data is in the form of annual financial statements. The variables in this research were classified into two; they are dependent variable and independent variable as shown in Table 4.1:

$$
\begin{gathered}
\text { Table } 4.1 \\
\text { Research Variabl }
\end{gathered}
$$

\begin{tabular}{|c|c|}
\hline Variable & Formula \\
\hline $\begin{array}{l}\text { Dependent variable: } \\
\text { Bankingstarus } \\
\text { Independent variable: }\end{array}$ & 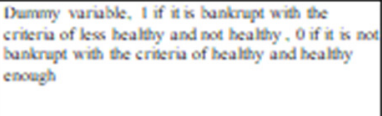 \\
\hline CAR & CAR = Capial / Asset with Risk $\times 100 \%$ \\
\hline LDR & LDR $=$ Loan so Deposit Ratio $\times 100 \% 6$ \\
\hline NPL & NPL = Now Performing Loans $\times 100 \%$ \\
\hline BOPO & $\begin{array}{l}\text { BOFO = Operational Fxpentes } \\
\text { Operational Inscome x } 100 \% \text {. }\end{array}$ \\
\hline ROA & 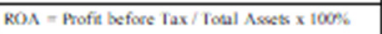 \\
\hline ROE & ROE = Net Profit / Equity x $100 \%$ \\
\hline NDM & NIM = Net Imerest/ Farning Asset $\times 10006$ \\
\hline
\end{tabular}

The object of this research is banking companies listed in Indonesia Stock Exchange during 2017 by using CAR, NPL, LDR, BOPO, ROA, ROE and NIM ratios for predicting bankruptcy in banking business. 
Tabel 4.2

Banking Companies Listed in Indonesia Stock Exchange

\begin{tabular}{|c|c|c|}
\hline No & Nama Bank & Kode \\
\hline 1 & BANK RAKYAT INDONESIA AGRO NIAGA TBK & AGRO \\
\hline 2 & BANKAGRIS TBK & AGRS \\
\hline 3 & BANK MNC INTERNATIONAL TBK & BABP \\
\hline 4 & BANK CAPITAL INDONESIA & BACA \\
\hline 5 & BANK CENTRAL ASIA TBK & BBCA \\
\hline 6 & BANK HARDA INTERNATIONAL TBK & BBHI \\
\hline 7 & BANK BUKOPIN TBK & BBKP \\
\hline B & BANK MESTIKA DHARMA TBK & BBMD \\
\hline 9 & BANK NEGARA INDONESIA TBK & BBNI \\
\hline 10 & BANK NUSANTARA PARAHYANGAN TBK & BBNP \\
\hline 11 & BANK RAKYAT INDONESIA [PERSERO]TBK & BBRI \\
\hline 12 & BANK TABUNGAN NEGARA [PERSERO] TBK & BBTN \\
\hline 13 & BANK YUDHA BHAKTI TBK & BBYB \\
\hline 14 & BANK DANAMON TBK & BDMN \\
\hline 15 & BANK PEMBANGUNAN DAERAH BANTEN TBK & BEKS \\
\hline 16 & BANK GANESHA TBK & BGTB \\
\hline 17 & BANK INA PERDANA TBK & BINA \\
\hline $1 \mathrm{~B}$ & BANK JABAR BANTEN TBK & B.BR \\
\hline 19 & BANK PEMBANGUNAN DAERAH JAWA TIMUR TBK & BUTM \\
\hline 20 & BANK QNB INDONESIA TBK & BKSW \\
\hline 21 & BANK MASPION INDONESIA TBK & BMAS \\
\hline 22 & BANK AMNDIRI [PERSERO] TBK & BMRI \\
\hline 23 & BANK BUMI ARTA TBK & BNBA \\
\hline 24 & BANK CIMB NIAGA TBK & BNGA \\
\hline 25 & BANK MAYBANK INDONESIA TBK & BNII \\
\hline 26 & BANK PERMATA TBK & BNLI \\
\hline 27 & BANKSINARMAS TBK & BSIM \\
\hline $2 B$ & BANK OF INDIA INDONESIA TBK & BSWD \\
\hline 29 & BANK TABUNGAN PENSIUNAN NASIONAL TBK & BTPN \\
\hline 30 & BANK VICTORIA INDONESIA TBK & BVIC \\
\hline 31 & BANK DINAR INDONESIA TBK & DNAR \\
\hline 32 & BANK ARTHA GRAHA INTERNATIONAL TBK & INPC \\
\hline 33 & BANK CHINA CONSTRUCTION BANK IND TBK & MCOR \\
\hline 34 & BANK MEGA TBK & MEGA \\
\hline 35 & BANK MITRANIAGA & NAGA \\
\hline 36 & BANK OCBC INSP & NISP \\
\hline 37 & BANK NATIONALNOBU TBK & NOBU \\
\hline $3 B$ & BANK PAN INDONESIA TBK & PNBN \\
\hline 39 & BANK PANIN SYARIAH TBK & PNBS \\
\hline 40 & BANK WOORI SAUDARA INDONESIA 1906 TBK & SDRA \\
\hline
\end{tabular}

Source :Indonesia Stock Exchange, Processed

\section{Findings and Discussion}

\section{Data Description}

In this research, statistical description is needed to analyze the data. The statistical description of the data for the year of 2017 is presented in Table 5.1.

Tabel 5.1

Statistical Descriptive Data in 2017 (in precentage)

Descriptive Statistics

\begin{tabular}{|l|r|r|r|r|r|r|}
\hline & $\mathrm{N}$ & Minimum & Maximum & \multicolumn{1}{c|}{ Sum } & Mean & Std. Deviation \\
\hline CAR & 40 & 11.43 & 23.72 & 546.74 & 16.5679 & 3.10312 \\
NPL & 40 & .10 & 3.61 & 38.50 & 1.1667 & .94769 \\
LDR & 40 & 56.86 & 113.15 & $2,825.06$ & 85.6079 & 10.99950 \\
BOPO & 40 & 55.35 & 184.90 & $2,654.26$ & 80.4321 & 22.45233 \\
ROA & 40 & -7.64 & 4.46 & 55.17 & 1.6718 & 2.00161 \\
ROE & 40 & -10.99 & 35.18 & 534.80 & 16.2061 & 9.56676 \\
NIM & 40 & 2.13 & 11.95 & 171.05 & 5.1833 & 2.27322 \\
Valid N (listwise) & 40 & & & & \\
\hline
\end{tabular}

Source: Processed secondary data 
CAR variable has minimum value $11.43 \%$ and maximum value $23.72 \%$. Meanwhile, the mean value $16.57 \%$ indicates the banks have high CAR value.

NPL variable has minimum value $0.10 \%$ and maximum value $3.61 \%$. The mean value $1.17 \%$ indicates the banks are capable to provide loans selectively.

LDR variable has minimum value $56.86 \%$ and maximum value $113.15 \%$. The minimum value indicates some of the banks are incapable to provide loans, whereas the maximum value indicates the banks are quite capable to market the funds. Meanwhile, the mean value $85.61 \%$ indicates the banks are liquid (less than $120 \%$ ).

BOPO variable has minimum value BOPO 55.35\% and maximum value $184.90 \%$. The mean value $80.43 \%$ indicate the average banks have good efficiency rate (less than 94\%) while the others need to perform efficiency.

ROA variable has minimum value $-7.64 \%$, maximum value $4.46 \%$ and mean value $1.68 \%$. Negative ROA value indicates some of the banks experienced loss. Nevertheless, the average banks gain high profit in which the value is $1.68 \%$ (higher than $1.25 \%$ ).

ROE variable has minimum value $-10.99 \%$, maximum value $35.18 \%$, and mean value $16.21 \%$. Negative ROE value indicates some of the banks experienced loss. However, the average banks gain high profit that can be seen from the mean value $16.21 \%$.

NIM variable has minimum value $2.13 \%$, maximum value $11.95 \%$, and mean value $5.18 \%$ which indicate the average banks has high rate of Net Interest Margin (the mean value is higher than $2 \%$ ).

Table 5.3

Fit Model Test 2013

\begin{tabular}{|l|l|r|}
\hline FIT MODEL TEST & & RESULT \\
\hline \multirow{2}{*}{-2 LogLikehood } & -2 LL Block Number O & 42.015 \\
\cline { 2 - 3 } & -2 LL Block Number 1 & 21.647 \\
\hline \multirow{2}{*}{$\begin{array}{l}\text { Cox \& Snell R Square } \\
\text { Nagelkerke R Square }\end{array}$} & Cox & 0.347 \\
\cline { 2 - 3 } & Nagel & 0.606 \\
\hline Hosmer and Lemeshow Test & Chi Square & 5.440 \\
\cline { 2 - 3 } & Sig & 0.709 \\
\hline
\end{tabular}

The table shows that the hypothesis model describe the input data from -2 Log Likelihood Block Number, Cox\& Snell R Square, Nagelkerke R Square, and also Hosmer and Lemeshow Test. Fit Model can be assessed from the statistical value $-2 \operatorname{LogL}$ without variable, only the constant value 42.015. After a new variable is added, the value $-2 \operatorname{LogL}$ decreased to 21.647 or 20.368 drops. In other words, the discrepancy of $-2 \operatorname{LogL}$ is significant. It means that the addition of independent variable would improve the fit model.

Meanwhile, the value of Cox Snell's R Square is 0.347 and Nagelkerke $\mathrm{R}^{2}$ is 0.606 means that dependent variable variability can be defined by $60.6 \%$ of independent variable.

Hosmer and Lemeshow's Test are applied to test the 0 hypothesis that the empirical data is proper and fit to the model (no differences between model and data). The statistic value of Hosmer and Lemeshow's Goodness Fit Test is 5.446 with significant probability 0.709 (above 0.05 ). Therefore, the model is accepted.

The logit test result for 2017 can be seen in the following table:

Table 54

Variable Equations in Logit Test

\begin{tabular}{|c|c|c|c|c|}
\hline DESCRIPTION & PREDICTION & B & SIG & EXP (B) \\
\hline CAR & Ngzays & -0.072 & 0.037 & 0,931 \\
\hline LDR & Posiare & -0.063 & $0.067^{\circ}$ & 0.939 \\
\hline NPI & Posidire & 0.019 & 0.043 & 1.019 \\
\hline BOPO & Posabirs & -0.097 & 0.020 & 0,908 \\
\hline ROA & Norats & 1.486 & 0.023 & 0.226 \\
\hline ROE & Nogatrs & -0.007 & 0.018 & 1.007 \\
\hline NI! & Nerats & -0.009 & 0.033 & 1.009 \\
\hline CONSTANT & & 8,376 & 0,663 & 0,000 \\
\hline
\end{tabular}

Improper variables in 2017 are LDR and ROA. LDR is negative due to incapability of the banks to spend the funds appropriately. As a result, the banks invest in the form of low-risk productive assets. The banks gain much interest income from these investments. ROA becomes positive because of high rate of profit, but the loans are low. The average value of NPL for the overall banks is $1.17 \%$. It indicates that the non-performing loans are less.

\section{CONCLUSIONS}

This study aims to examine and analyze the significant effect of CAR, LDR, NPL, BOPO, ROA, ROE, and NIM financial ratios on bank bankruptcy. The data used in this study are data of banking companies that are known as the Indonesia Indonesia Securities in 2017. The total population of 40 banks can be used in this study. Hypothesis testing uses multivariate test with logit regression. The results of the study did not accept Ha overall.

The variable that is influential in explaining bank bankruptcy is the LDR. In accordance with the results of the logit test, it can be concluded that bank bankruptcy is caused by the ability to market funds not maximally so 
that banks invest funds collected in the form of other productive assets that are not at risk.

Based on the conclusions above, a number of suggestions are expected to be useful for the company and for other parties:

1) The negative effect of LDR on the probability of bankruptcy of a bank shows that the function of banks in lending has not gone well so that an idle fund occurs that can affect bank bankruptcy. To maintain liquidity at the same time so that the bank does not experience bankruptcy, management can plan the marketing of bank service products and place idle funds in the form of productive assets other than credit.

2) Further research should extend the research period and consider factors other than financial ratios, such as size, compliance aspects such as percentage violations of the Lending Limit, percentage exceeding the Maximum Lending Limit, Minimum Statutory Reserves and Net Open Position.

3) The negative influence of the LDR on the probability of bankruptcy of the bank shows that the bank's function in channeling credit has not gone well so that there is an idle fund that can affect the bank's bankruptcy. To maintain liquidity at the same time so that the bank does not experience bankruptcy, management can plan the marketing of bank service products and place idle funds in the form of productive assets other than credit.

4) Further research should extend the research period and consider factors other than financial ratios, such as size, compliance aspects such as percentage violations of the Lending Limit, percentage exceeding the Maximum Lending Limit, Minimum Statutory Reserves and Net Open Position.

\section{References}

Altman, E. I. 1968. "Financial Ratios, Discriminant Analysis and The Prediction of Corporate Bankruptcy." The Journal of Finance, Vol. 23, No.4, pp.589-609.

BarNiv Ran and James B McDonald. (1992). Identifying financial distress in the insurance industry: A Synthesis of method, Journal of Risk and Insurance (1986-1998) 59, 4; ABI/INFORM Global pg.543.

BarNiv Ran and James B McDonald. (1992). Identifying financial distress in the insurance industry: A Synthesis of method, Journal of Risk and Insurance (1986-1998) 59, 4; ABI/INFORM Global pg.543.

BarNiv Ran and James B McDonald. (1992). Identifying financial distress in the insurance industry: A Synthesis of method, Journal of Risk and Insurance (1986-1998) 59, 4; ABI/INFORM Global pg.543.

Barniv Ran and James B McDonald. (1992) Indentifyingfinancial distress in the insurance industry: ASynthesis of method, Journal of Risk and Insurance (1986-1998) 59,4; ABI/INFORM Global pg.543.

Darsono,P. (2006). Manajen Keuangan. Jakarta: Gramedia.

Endri. (2009). Prediksi Kebangkrutan Bank Untuk Menghadapi Dan Mengelola Perubahan Lingkungan Bisnis: Analisis Model Altman's Z-Score. Perbanas Quarterly Review, 2(1).

Foster, G. 1986. Financial Statement Analysis. $2^{\text {nd }}$ Ed. Prentice Hall

Fraser, Lyn M. \& Ormiston Aileen.(2004). Memahami Laporan Keuangan. Edisi Keenam. Jakarta: Indeks.

Ganiarto, F. K. dan A. Ibad. 2003.'Meneropong Kesanggupan Beberapa Bank di DKI Jakarta untuk Memenuhi Ketentuan Rasio NPL Maksimum 5\% pada Juni 2003.” JBII, Vol. 10, No.1

Ghozali, Imam. 2005. Aplikasi Analisis Multivariate dengan Program SPSS. Badan Penerbit Universitas Diponegoro

Hair, J.F., W.C. Black, B.J. Babin, R. E. Anderson, R. L. Tatham. 2006. Multivariate Data Analysis. $6^{\text {th }}$ Ed. Pearson International Edition

Harahap, Sofyan Syafri. (2008). Analisis Kritis atas Laporan Keuangan. Jakarta: PT.Raja Grafindo Persada.

http://www.idx.co.id/perusahaan-tercatat/laporan-keuangan-dan-tahunan/

https://www.ojk.go.id/id/kanal/perbankan/data-dan-statistik/statistik-perbankanindonesia/Documents/pages/statistik-perbankan-indonesia---november-2018/SPI\%20November\%20

Januarti, Indira. 2002. "Variabel Proksi CAMEL dan Karakteristik Bank Lainnya untuk Memprediksi Kebangkrutan Bank di Indonesia." Thesis Tidak Dipublikasikan, Magister Akuntansi, Universitas Diponegoro

Kuncoro, M. dan Suhardjono. 2002. Manajemen Perbankan Teori dan Aplikasi. Ed. 1. BPFE Yogyakarta

Meyer, P. A. and \& HW Pifer. 1970. "Prediction of Bank Failures." Journal of Finance. September, pp. 853 - 868

Munawir, S. (2007). Analisa Laporan Keuangan. Edisi keempat. Yogyakarta : Liberty.

Oktasari, Dian Primanita (2015). Analisis Rasio Keuangan Sebagai Alat Prediksi Kemungkinan Kebangrutan Pada Perusahaan Perbankan Yang Tercatat Di BEI.

Platt, H. D. and M. B. Platt. 2002. "Predicting Corporate Financial Distress: Reflecting on Choice-Based Sample Bias." Journal of Economics and Finance, Vol. 26, No. 2, pp.184 - 199.

Veithzal Rivai dan Andria Permata Veithzal.2007.”Credit Management Handbook.” Jakarta:Raja Grafindo 
Persada.

Sawir, A. 2005. Analisis Kinerja Keuangan Perusahaan. Ed. 3. PT.Gramedia Pustaka Utama

Sekaran, Uma dan Bougie, Roger. 2013. Research Methods for Business. United Kingdom: Jhon Wiley \& Sons Ltd.

Sinkey, J. F Jr. 1975. "A Multivariate Statistical Analysis of The Characteristic of Problem Bank." Journal of Finance, Vol. XXX, No. 1, March, pp. $21-36$

Suharman, H. 2007. “Analisis Risiko Keuangan untuk Memprediksi Tingkat Kegagalan Usaha Bank.” Jurnal Imiah ASET, Vol. 9, No. 1 Februari

Riyadi, S. 2006. Banking Assets and Liability Management. Ed. 3. Lembaga Penerbit Fakultas Ekonomi Universitas Indonesia 